\title{
A PROJECT MANAGEMENT INVESTIGATIVE FRAMEWORK ESTABLISHING LINKS FOR BETTER PROJECT OUTCOMES
}

\author{
R. Siriram ${ }^{1 *}$
}

\section{ARTICLE INFO}

\section{Article details}

Submitted by authors $\quad 30$ Sep 2018 Accepted for publication 11 Jul 2019 Available online $\quad 30$ Aug 2019

\section{Contact details}

* Corresponding author raj@alpha-concepts.com

Author affiliations

1 School of Mechanical, Industrial and Aeronautical Engineering, University of the Witwatersrand, Johannesburg, South Africa

\section{DOI}

http: //dx.doi.org/10.7166/30-2-2064
ABSTRACT

This paper makes a contribution to knowledge by proposing a project management (PM) investigative framework with seven constructs and 60 sub-scales. The research consisted of an eightstep process. First, a project management assessment (PMA) tool was developed through an extensive literature review. Second, the PMA tool was evaluated through an expert panel. Third, the PMA tool was used to evaluate 330 projects, producing 330 PMA results. Fourth, an investigative framework linking the different PMA constructs was developed and tested. Structural equation modelling (SEM) was used to find links in the investigative framework for each of the PMA constructs, and 19 hypotheses were tested, all of which were accepted. The results provide interesting lessons for researchers and for project management practitioners. Finally, a discussion of the results, the study's limitations, and suggestions for further research are presented. .

\section{OPSOMMING}

Hierdie artikel lewer 'n bydrae tot die literatuur deur 'n projekbestuur ondersoekende raamwerk voor te stel met sewe konstrukte en 60 sub-skale. Die navorsing bestaan uit 'n proses met agt stappe. Eerstens is 'n projekbestuur assesseringsgereedskapstuk (PMA) ontwikkel deur ' $n$ uitgebreide literatuurstudie. Tweedens is die gereedskapstuk evalueer deur 'n paneel van kundiges. Derdens is die gereedskapstuk gebruik om 330 projekte te evalueer. Vierdens is 'n ondersoekende raamwerk wat die verskillende PMA konstrukte koppel ontwikkel en getoets. Strukturele vergelyking modellering is gebruik om skakelinge in die ondersoekende raamwerk vir elkeen van die PMA konstrukte op te spoor en 19 hipotese is getoets, waarvan almal aanvaar is. Die resultate verskaf interessante lesse vir navorsers en projekbestuurders. Laastens word ' $n$ bespreking van die resultate, die beperkinge en voorstelle vir verdere navorsing voorgehou.

Siriram [1] has pointed out that "many firms face out of control projects and many report huge losses. Firms are hampered with many failures in project management, and the causes of these failures vary e.g. embedding of project management (PM) initiatives, poor quality, cost and schedule slippage, immature processes, adherence to processes, coordination of information flow, knowledge transfer, trust in project relationship, and etc." An abundance of research evidence supports poor project outcomes; it is neither the intention nor necessary to give a complete review here. Siriram [2] has given an elaborate overview of research in project management. For the sake of completeness, it is important to mention at least the following research in support of poor project outcomes: Miller and Lessard [3] and Shehu, Endut and Akintoye [4]. Other issues have also been raised by Young, Young and Jordaan [5] (deficiencies in project execution) and by Atkinson, Crawford and Ward [6] (highlighting uncertainties in projects and the scope of PM). Based on at least this 
research evidence, the central research question posed is as follows: What are the different factors in a project that contribute to better project outcomes?

Siriram [2] has pointed to the need to develop PM as a capability that is required to meet a firm's strategic goals and improve its competitive advantage. Tahri and Drissi-Kaitounib [7] argue that there is no generally agreed definition of what a mature project organisation looks like; so a growing number of maturity models are being developed to assess project management maturity. Siriram [2] proposed that project management assessments (PMAs) are the basis for setting up PM capabilities, and defined PMAs as "a tool that an organisation may use to assess its project management maturity, compare to its own practises against best practises with the intention of mapping out a path to improvement". This paper builds on this foundation. A PMA consists of different constructs. In this paper, these constructs are used as the basis of a PM investigative framework. Using this framework, the links between the PMA constructs are explored. Further evidence to develop PM as a capability is provided by Fringsdorf, Zuo and Xia [8], who identify critical success factors for project efficiency. They argue that those factors need to be developed to ensure successful project outcomes, and that these factors are not limited to individual project factors, but extend to include project interdependencies and external customers. Fernandes, Ward and Araújo [9] argue that there is a need to embed project management practices within firms. Some researchers, such as Jaafari [10], have identified project and programme diagnostics as a systemic approach to project management maturity and evaluation. Qureshi, Warraich and Hijazi [11] have proposed PMA models. Therefore, based on this research evidence, PMAs are seen to be important, and are used as the basis to establish a PM investigative framework that may be used to improve project outcomes.

This paper makes a contribution to knowledge by trying to establish a PM investigative framework that would integrate the different constructs/factors in a project and, in so doing, enable project managers and business managers to improve project outcomes.

The objectives of this paper are as follows:

a) To develop a PMA tool through a literature survey and expert panel analysis;

b) To use the PMA tool to assess projects;

c) To use the PMAs to develop a PM investigative framework;

d) To test the PM investigative framework using structural equation modelling (SEM); and

e) To identify opportunities for further research.

Some firms are project-driven; and in such firms PM is seen as a capability to develop competitive advantage [2]. However, while not all firms are project-based, for those firms that are, the importance of PM has already been pointed out. For firms that are not project-based, Canonico and Soderlund [12] point out that more firms are being managed through projects, and it is difficult to imagine a firm that is not managed through some kind of project activity. Therefore, PM is seen as an important factor for project-based firms as well as for non-project-based firms. Clearly PM is important in driving competitive capabilities; therefore, this research is directed towards establishing a greater understanding of links in a PM investigative framework.

\section{LITERATURE SURVEY AND HYPOTHESIS DEVELOPMENT}

Siriram $[1,2]$ has already given an extensive overview of research in project management, and has pointed out [2] that, given the importance of PMAs, little work has been done on them. He identified PMAs as the basis on which to develop project management maturity. Baker and Fisher [13] identified factors affecting project success; and from the research evidence it is apparent that poor project outcomes are a concern. The mitigation of poor project outcomes is needed.

It is proposed that a PM investigative framework be developed that links the different constructs used in PMAs. Many researchers have pointed out the importance of PMAs from various perspectives: project maturity models (Crawford [14], Jugdev \& Thomas [15], Mittermaie \& Steyn [16]), programme diagnostics (Jaafari [10]); and project assessment models (Qureshi, Warraich \& Hijazi [11]). Given the importance of PMAs, it would be beneficial to understand which constructs/factors should be included in a PMA tool. From the literature review, the following seven constructs have been identified as important; definitions/descriptions of each of the constructs are also provided:

1. Project organisation and leadership: The descriptors for this construct are as used by Siriram [2], where 'project organisation' is defined as the human infrastructure of the project, and 
includes the project organisation chart and roles and relationships [17]. This definition is expanded by Siriram [2] to include project ownership and the behaviour of executives - i.e., project leadership. Project monitoring and control is excluded from the definition used by Siriram [2]; in this paper it is treated as a separate construct, and 'project organisation' includes project organisation and leadership.

The importance of project organisation and leadership is supported by Chen and Lin [18], who propose that goal orientations through leader-leader exchange and trust affect overall project performance; Fernandes, Ward and Araújo [9] support improving and embedding project management practices in organisations; Guangshe, Yuting, Xiangdong, Jianguo, Jiming and Kewei [19] support project organisation maturity; and Aubry, Muller, Hobb and Blomquist [20] point to the importance of project management offices. Project organisation and leadership is seen as an important driver for project management practices. Research evidence of this is given by Kolltveit, Karlsen and Grønhaug [21], who highlight the importance of project management leadership and task and business perspectives. Further support for this is given by Yang, Huang and Wu [22] on project manager leadership styles, team work, and project success. Therefore project organisation and leadership is seen as important.

2. Project control and monitoring: Collyer and Warren [23] define 'project control' to mean the mechanism through which resources are managed to achieve project objectives. In this paper, 'project control and monitoring' is taken to include the aspects of controlling cost and time. Siriram [2] identifies 'project financial control' as important, and includes it as a sub-scale of project organisation. Here it is treated as a separate construct, and defined as the control and monitoring of cost and time that is required for effective project governance. Project controlling and monitoring is seen as an important part of evaluating the performance of a project.

Research evidence in support of project control and monitoring is found in the following work. Effective project monitoring and control is achieved by assessing project performance and evaluation (Cao \& Hoffman [24]), project monitoring and evaluation (Crawford \& Bryce [25]), the use of analytical models and decision support tools for project monitoring and control (Hazir [26]), and project management governance and the normalisation of deviance (Pinto [27]). Crawford and Bryce [25] propose project monitoring and evaluation as a method for enhancing the efficiency and effectiveness of project implementation. Therefore, project control and monitoring is an important construct.

3. Project structuring: Siriram [2] describes a project structure plan as consisting of at least the following: a proper project plan (e.g., bar chart, network diagram, critical path analysis) that is a realistic representation of the project; clearly separated work packages with clear handover points; clear time lines of communication; and an accurate representation of the stakeholders.

Globerson [28] points out that for "a large project to be properly planned and executed, it must be 'decomposed' into small segments in a structural manner. The planning and execution of these segments is then assigned to specific organizational units. This 'slicing' approach is called the work-breakdown structure". Further evidence in support of the work-breakdown structure is given by Larenas and Scasso [29], who say that the work-breakdown structure is the instrument that is used to model a project and to represent its sub-systems and units and their relationships. Bjorvatn and Ward [30] argue that project complexity leads to project delays and hampers project performance. Therefore, project structuring is considered an important construct that should be incorporated into a PM investigative framework. Zammori, Braglia and Frosolini [31] point out that it is not necessary to argue that most projects encompass risk and are difficult to manage; therefore, several network techniques have been researched to structure projects better. Thus project structuring is an important construct to be considered in the PM investigative framework.

4. Project schedule, resources, and procurement: Siriram [2] identified project schedule, resources, project milestones, and project planning as an important sub-scale in a construct called 'project planning, engineering design and quality'. In this context, 'project schedule resources and procurement' is treated as a separate construct in the PM framework. Siriram [2] also identified procurement as an important element within this construct. However, 
project quality is treated as a separate construct (point 6 below), while 'engineering design' is not included as a construct or sub-scale in this research.

Siriram [2] saw resource planning to include the allocation of the necessary resources (Material, finance and personnel) to work packages and the decomposition of the project plan into sensible phases with clear deliver milestones.

5. Project scope creep and variation: PMBOK [17] defines 'risk' as the process concerned with risk management planning, identification, analysis, response, and monitoring and control of the project. Siriram [2] expanded this definition to include project scope creep and variation. A project needs to have a proper process in place to cover change and claims management, and a proper close-out process to mitigate the risks associated with project scope creep and variation.

Atkinson, Crawford and Ward [6] point to the fundamental uncertainties in projects and the scope of project management.

6. Project risk and quality: In this paper we expand the PMBOK [17] definition of 'project risk' (mentioned in point 5 ) to include project risk and quality. A project may face potential risk due to bad quality; thus risk and quality are seen as coupled together. Also following on from point 5 , further risks are associated with project scope creep and variation, and these risks may influence project quality.

Several researchers have highlighted the importance of project risk and quality, including the following: Basu [32] did an empirical study of quality in projects; project risk (Kwak \& Smith [33]); risk perception analysis (Choi, Chung \& Lee [34]); risk efficiency (Chapman \& Ward [35]); risk and uncertainty (Chapman [36]); project risk (Van Os, Berkel, De Gilder, Van Dyck and Groenewegen [37]); and project risk management and its influence on project portfolio success (Teller \& Kock [38]). Clearly, project risk and quality is an important construct to include in the project management investigative framework.

7. Project completion: PMBOK [17] defines 'project close-out' as those activities that formally close the project, phase, or contractual obligations. Aziz [39] points out that many organisations overlook project close-out; however, the failure to close-out projects could "a) put the organisation at a considerable amount of risk, b) prevent the organisation from realising anticipated benefits from project deliverables, c) result in significant losses to the organisation and d) undermine the project manager and project team's credibility". Therefore, project completion is seen as an important construct to be included in the PM investigative framework.

The thrust of this paper is to build a PM investigative framework to improve PM maturity in organisations. PMA data is collected from 330 projects from across four industry sectors. Given the importance of project management maturity, the role of PMAs in achieving project management maturity, and the need to improve and embed project management practices, further empirical evidence specifically on PMAs may assist researchers and practitioners in their study of project management. Using PMAs as a basis, a PM investigative framework is constructed that shows how the different constructs link to project completion. The seven constructs are depicted in Figure 1, which is used as a basis for the development of the hypotheses.

The following model is proposed: 


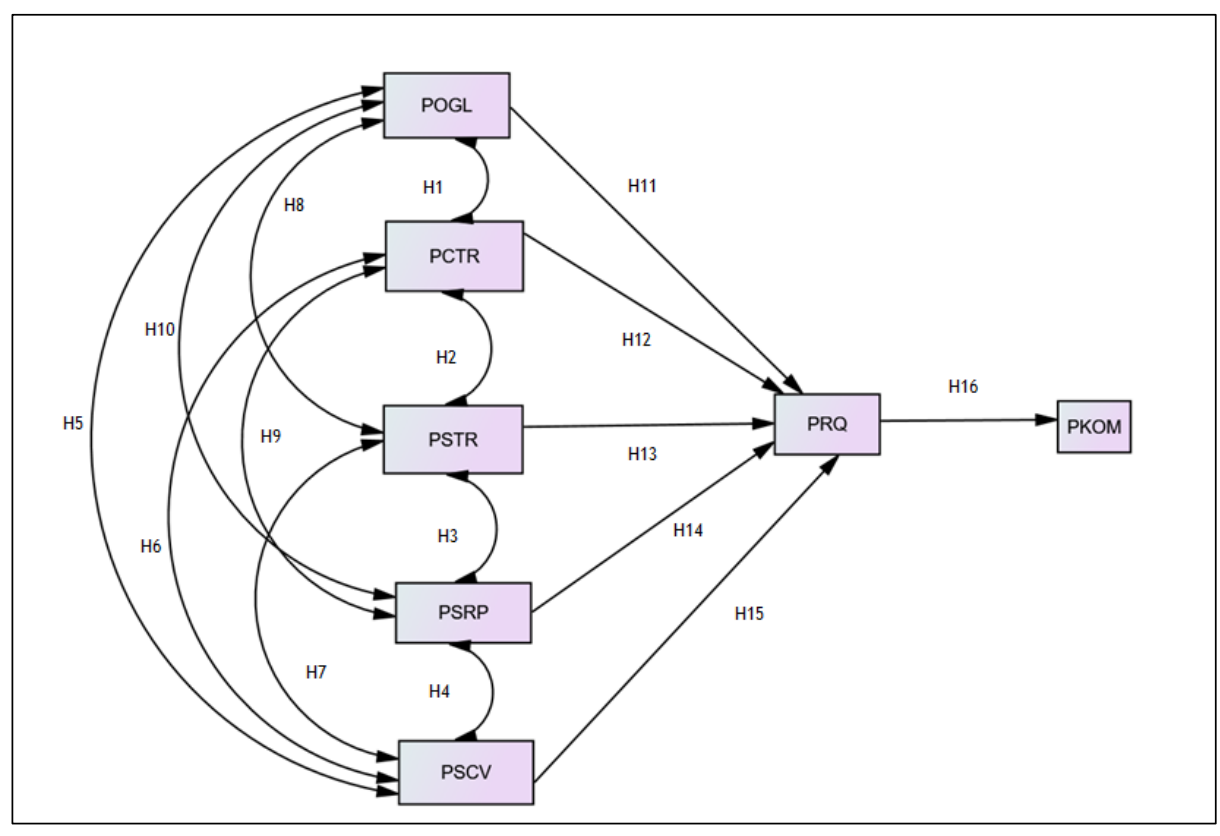

Figure 1: PM Investigative framework

\subsection{Hypothesis development}

Wang, Liu and Canel [40] highlight the importance of coordinating activities in project implementation between firms. Görög [41] points out that project planning and control are twin brothers in the project implementation process: planning does not make sense without control, while control cannot be done without plans. Moreover, when Siriram [2] identified links in a PM framework, he found that project organisation and leadership would result in better project control and performance management, and found links to project risk, the overall project result, and project planning. In this paper, the drivers of project organisation are also considered to be important. Siriram [2] combined different factors into project organisation - for example, behaviour of executives, financial control, and project structure. In this study we treat these factors as separate constructs. The approach taken is that project organisation and leadership is an important starting point that will drive project control and monitoring, project structuring, project scheduling, resources and procurement, and project scope creep and variation. Thus the following hypotheses are formulated:

$\mathrm{H} 1$ : Project organisation and leadership (POGL) is positively linked to project control and monitoring (PCTR).

H2: Project control and monitoring (PCTR) is positively linked to project structuring (PSTR).

H3: Project structuring (PSTR) is positively linked to project scheduling, resources, and procurement (PSRP).

H4: Project scheduling, resources, and procurement (PSRP) is positively linked to project scope creep and variation (PSCV).

Jaafari [10] argues that management excellence affects project success, and further posits that project success is linked to project resources, capabilities, managerial approach, and commercial and physical environment. Therefore, the constructs 'project organisation and leadership', 'project control and monitoring', 'project structuring', 'project scheduling, resources, and procurement', and 'project scope creep and variation' (PSCV) are seen as linked to each other. Thus the following hypotheses are proposed.

H5: Project scope creep and variation (PSCV) is positively linked to project organisation and leadership (POGL).

H6: Project scope creep and variation (PSCV) is positively linked to project control and monitoring (PCTR).

H7: Project scope creep and variation (PSCV) is positively linked to project structuring (PSTR).

H8: Project structuring (PSTR) is positively linked to project organisation and leadership (POGL). 
H9: Project scheduling, resources, and procurement (PSRP) is positively linked to project control and monitoring (PCTR).

H10: Project scheduling, resources, and procurement (PSRP) is positively linked to project organisation and leadership (POGL).

El-Sayegh [42] defines 'project risk' as an uncertain event or condition that, if it occurs, has a positive or negative effect on at least the project objective, such as time, cost, scope, or quality. Schwalbe [43] stated that the "purpose of project quality management is to ensure that the project meets its expectations". Tam and Le [44] say that "project management involves meeting or exceeding stakeholder needs and expectations; the project team must develop good relationships with key stakeholders, especially the main customers, so that the concept of quality is thoroughly understood". Schwalbe [43] points out, therefore, that quality must be on an equal level with project scope, time, and cost. Furthermore, Zhang [45] argues that project systems could have a mediating influence on the risk links. Therefore, the constructs of project organisation and leadership, project control and monitoring, project structuring, project scheduling, resources, and procurement, and project scope creep and variation are seen as potentially linked to project risk and quality. Hence the following hypotheses are formulated:

H11: Project organisation and leadership (POGL) is positively linked to project risk and quality (PRQ). H12: Project control and monitoring (PCTR) is positively linked to project risk and quality (PRQ).

H13: Project structuring (PSTR) is positively linked to project risk and quality (PRQ).

$\mathrm{H} 14$ : Project scheduling, resources, and procurement (PSRP) is positively linked to project risk and quality (PRQ).

H15: Project scope creep and variation (PSCV) is positively linked to project risk and quality (PRQ).

El-Sayegh [42] points out that risks are related to rewards. Some risks should be accepted as long as they are in line with the rewards; and a failure to deal with risks has been shown to cause cost and time overruns. Van Wyk, Bowen and Akintoye [46] point out that risk management continues to be a major concern in large construction, engineering, and technological projects in the attempt to reduce uncertainties and improve project success. Jha and lyer [47] argue that there is no universally accepted definition of 'project success', and have pointed that project performance is traditionally evaluated in terms of schedule, cost, and quality. Therefore, project risk and quality is an important node in the PM investigative framework (project schedule has already been discussed under the project scheduling, resources, and procurement construct), and is seen to influence project completion. Thus the following hypothesis is formulated:

H16: Project risk and quality (PRQ) is positively linked to project completion (PKOM).

This research also provides the basis for further research into PMAs as a tool, to gain a better understanding of a PM investigative framework; and this understanding may lead to the development of PM as a capability. The research methodology is discussed next.

\section{RESEARCH METHODOLOGY}

\subsection{The 8-Step research process}

The research methodology consisted of the eight-step process depicted in Figure 2. Each of the steps in Figure 2 is next discussed:

Step [1]: A literature survey was conducted to establish constructs that could be used to establish a PMA tool.

Step [2]: Once the constructs were identified, a PMA instrument, consisting of seven constructs, was constructed.

Step [3]: The PMA instrument was tested using a pre-test group, for clarity, structure, wording, and relevance. The pre-test group consisted of 13 participants. The participants in the pre-test and pilot group were individuals who held senior and executive PM roles such as projects director, general manager projects, head-of projects, senior project management, and project manager.

Step [4]: This step consisted of two sub-steps. First, the PMA instrument was reviewed by an expert panel consisting of 15 people who held senior PM positions in large organisations that ranged in size 
from a thousand to more than 6,000 employees. They reviewed the PMA instrument to ensure that the constructs and sub-scales were relevant to PM industry standards and conformed to accepted norms such as PMBOK [17]. Second, 32 PMAs were conducted in selected firms (the pilot group); these were drawn from the research sample (refer to point 5 of this section). Thereafter Cronbach's alpha tests were conducted, and values below 0.7 were removed from the analysis [2].

Step [5]: Identification and selection of firms participating in the research. The firms were chosen specifically for their willingness to participate in the research. It proved to be difficult to find firms to participate in this research, as it includes an in-depth evaluation of a firm's project management practices and results. Firms in the population were chosen from Fortune 500 companies that operate in South Africa, firms listed on the Johannesburg Stock Exchange, and other large firms that were not on the Fortune 500 list or the Johannesburg Sstock Exchange, but whose core business was delivered through projects.

A total of 1,163 firms were identified, of which 330 firms participated in the research, yielding a response rate of 28.374 per cent. The main reason for the high response rate was that the author was able to solicit responses from firms through his professional and personal networks. The firms that participated in the research operated across four different industry sectors: the electronics and electrical engineering industry, the information and communication technology industry, the mining industry, and rail manufacturing industries. PMAs were then conducted with each of the firms. The PMA instrument was completed by the author in conjunction with participants from each of the firms. The PMA process ranged over an eighteen-month period, during which 330 PMAs were conducted.

Step [6]: The PMAs were statistically analysed. SPSS version 25.0 was used for the statistical analysis.

Step [7]: The PMA results were assessed by an expert panel with whom two review sessions were held. Each review session lasted two hours.

Step [8]: The research results are reported.

The research results are next discussed.

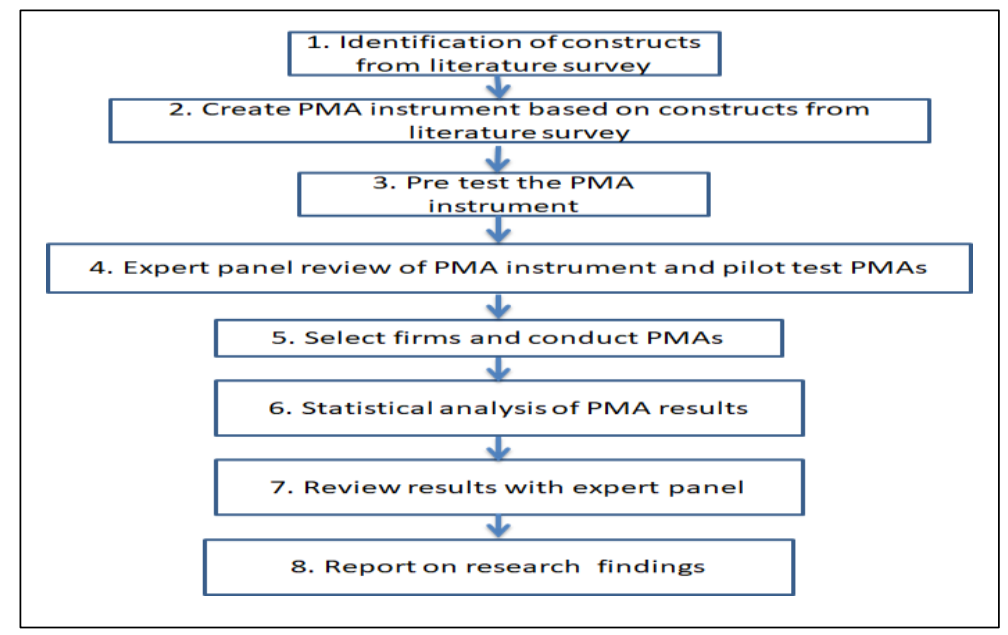

Figure 2: Research methodology

\subsection{Analysis of results}

Table 1 summarises the profile of the research sample. The sample was checked for sample representivity. Chi-squared distribution analyses revealed no significant differences between our sample and the population from which it was drawn in terms of industry distribution, number of employees, and firm size. Table 2 gives the confirmatory factory analysis.

In addition, the discriminant validity of the instrument was verified by comparing the average variance extracted of each latent construct with the square of the correlation between this 
construct and every other construct used in the research [2]. The result is shown in Table 3, confirming the discriminant validity: the square of the average variance extracted for each construct is greater than the levels of correlation involving the construct. The results of the inter-construct correlations also show that each construct shares larger variance with its own measures than with other measures.

Table 1: Profile of research sample

\begin{tabular}{|c|c|c|c|c|}
\hline \multirow[t]{2}{*}{ Description } & \multicolumn{4}{|c|}{ Firm } \\
\hline & Alpha? & Beta? & Gamma? & Phi ? \\
\hline Sector & Electronics and electrical & ICT & Mining & Manufacturing Rail \\
\hline Turnover & > R 7 Billion & > R 10 Billion & > R 6 Billion & $>15$ Billion \\
\hline Number of employees & ?5000 & $? 6000$ & $? 5000$ & ?1000 \\
\hline Operating regions & $\begin{array}{l}\text { Southern African } \\
\text { developing countries }\end{array}$ & $\begin{array}{l}\text { Middle East and } \\
\text { Africa }\end{array}$ & $\begin{array}{l}\text { Southern African } \\
\text { developing countries }\end{array}$ & $\begin{array}{l}\text { Southern African } \\
\text { developing } \\
\text { countries }\end{array}$ \\
\hline Project size & R10M to R380M & R5M to R80M & R2OM to $200 \mathrm{M}$ & R5M to $\mathrm{R} 900 \mathrm{M}$ \\
\hline Number of projects & 102 & 126 & 54 & 48 \\
\hline
\end{tabular}

First, as suggested by Anderson and Gerbing [48], the 99 per cent confidence intervals around the correlation parameter estimates between all possible pairs of scales, and established that none of these intervals included one. Second, the square of the correlation between any two constructs was less than the average extracted estimates. Overall, the results showed an adequate level of reliability and validity.

\subsection{The structural model}

Structural equation modelling was used to test the PM investigative framework. The model was developed using AMOS 25.0. For the model fit indices the methodologies given by Hair, Anderson, Tatham and Black[49], Yang and Su [50], and Williams and Hazer [51] were used. 330 responses were received for the structural equation modelling, which is acceptable $\left(>5^{*}\right.$ no. of distinct parameters, $5 * 60=300[49])$.

The model has a chi-squared value of 1.199 and 1 degrees of freedom. The chi-squared statistical significance level of 0.274 is above the minimum level of 0.05 and more conservative levels of 0.10 . This indicates that the model is a good fit. Table 4 shows the model fit indices. The normed chisquare $(\mathrm{X} 2 / \mathrm{df})$ has a value of 1.199 . This falls well within the recommended levels of 1.0 to 2.0 [49]. The goodness of fit index (GFI) of 0.961 is also quite high; adjusting for model parsimony, the adjusted goodness of fit index (AGFI) value is 0.903 , which is acceptable. The incremental fit indices - i.e., the Tucker-Lewis index (TLI) and the normed fit index (NFI) - are 0.995 and 0.999 respectively, and above the recommended level of 0 .. The RMSEA is at 0.037 , below the suggested threshold value of 0.08 .

The research results are discussed next. 
Table 2: Confirmatory factor analysis

\begin{tabular}{|c|c|c|c|c|c|c|c|c|c|}
\hline 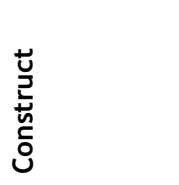 & 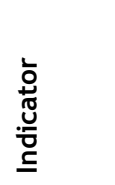 & 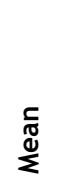 & 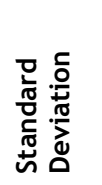 & 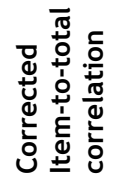 & 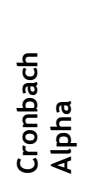 & 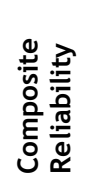 & 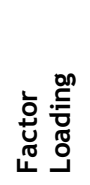 & 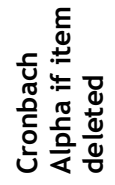 & 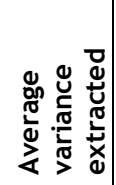 \\
\hline $\begin{array}{l}\text { Project } \\
\text { organisation } \\
\text { and } \\
\text { leadership }\end{array}$ & $\begin{array}{l}\text { POGL1 } \\
\text { POGL2 } \\
\text { POGL3 } \\
\text { POGL4 } \\
\text { POGL5 } \\
\text { POGL6 } \\
\text { POGL7 } \\
\text { POGL8 } \\
\text { POGL9 } \\
\text { POGL10 } \\
\text { POGL11 } \\
\text { POGL12 } \\
\text { POGL13 }\end{array}$ & $\begin{array}{l}3.52 \\
3.29 \\
3.27 \\
3.21 \\
3.44 \\
3.79 \\
3.69 \\
3.67 \\
3.36 \\
3.43 \\
3.40 \\
3.31 \\
3.68\end{array}$ & $\begin{array}{l}1.531 \\
1.740 \\
1.608 \\
1.477 \\
1.282 \\
1.354 \\
1.447 \\
1.450 \\
1.568 \\
1.392 \\
1.269 \\
1.248 \\
1.271\end{array}$ & $\begin{array}{l}0.796 \\
0.817 \\
0.637 \\
0.730 \\
0.602 \\
0.458 \\
0.640 \\
0.718 \\
0.727 \\
0.548 \\
0.492 \\
0.401 \\
0.380\end{array}$ & 0.905 & 0.710 & $\begin{array}{l}.900 \\
0.939 \\
0.878 \\
0.905 \\
0.778 \\
0.797 \\
0.820 \\
0.848 \\
0.803 \\
0.769 \\
0.770 \\
0.688 \\
0.680\end{array}$ & $\begin{array}{l}0.889 \\
0.882 \\
0.897 \\
0.892 \\
0.898 \\
0.904 \\
0.896 \\
0.893 \\
0.892 \\
0.900 \\
0.902 \\
0.906 \\
0.906\end{array}$ & 0.667 \\
\hline $\begin{array}{l}\text { Project } \\
\text { controlling } \\
\text { and } \\
\text { monitoring }\end{array}$ & $\begin{array}{l}\text { PCTR1 } \\
\text { PCTR2 } \\
\text { PCTR3 } \\
\text { PCTR4 } \\
\text { PCTR5 } \\
\text { PCTR6 } \\
\text { PCTR7 } \\
\text { PCTR8 }\end{array}$ & $\begin{array}{l}3.59 \\
3.37 \\
3.71 \\
3.05 \\
3.48 \\
3.35 \\
3.91 \\
3.61\end{array}$ & $\begin{array}{l}1.270 \\
1.288 \\
1.167 \\
1.437 \\
1.469 \\
1.356 \\
1.206 \\
1.279\end{array}$ & $\begin{array}{l}0.711 \\
0.618 \\
0.815 \\
0.492 \\
0.555 \\
0.611 \\
0.733 \\
0.597\end{array}$ & 0.873 & 0.642 & $\begin{array}{l}0.715 \\
0.709 \\
0.704 \\
0.730 \\
0.784 \\
0.843 \\
0.792 \\
0.792 \\
\end{array}$ & $\begin{array}{l}0.843 \\
0.853 \\
0.844 \\
0.869 \\
0.862 \\
0.854 \\
0.842 \\
0.856\end{array}$ & 0.578 \\
\hline $\begin{array}{l}\text { Project } \\
\text { structuring }\end{array}$ & $\begin{array}{l}\text { PSTR1 } \\
\text { PSTR2 } \\
\text { PSTR3 } \\
\text { PSTR4 } \\
\text { PSTR5 } \\
\text { PSTR6 } \\
\text { PSTR7 } \\
\text { PSTR8 } \\
\text { PSTR9 } \\
\text { PSTR10 } \\
\text { PSTR11 } \\
\text { PSTR12 } \\
\text { PSTR13 } \\
\text { PSTR14 }\end{array}$ & $\begin{array}{l}3.77 \\
3.76 \\
3.55 \\
3.41 \\
3.51 \\
3.50 \\
3.85 \\
3.43 \\
3.54 \\
3.58 \\
3.68 \\
3.62 \\
3.09 \\
3.03\end{array}$ & $\begin{array}{l}1.3050 \\
1.1870 \\
1.2250 \\
1.2770 \\
1.2480 \\
1.4310 \\
1.3060 \\
1.2890 \\
1.2900 \\
1.4190 \\
1.2360 \\
1.2960 \\
1.5220 \\
1.5910\end{array}$ & $\begin{array}{l}0.747 \\
0.615 \\
0.726 \\
0.716 \\
0.628 \\
0.798 \\
0.637 \\
0.591 \\
0.710 \\
0.825 \\
0.768 \\
0.708 \\
0.700 \\
0.737\end{array}$ & 0.941 & 0.723 & $\begin{array}{l}0.867 \\
0.813 \\
0.793 \\
0.742 \\
0.787 \\
0.908 \\
0.759 \\
0.838 \\
0.743 \\
0.877 \\
0.791 \\
0.803 \\
0.916 \\
0.911\end{array}$ & $\begin{array}{l}0.936 \\
0.939 \\
0.936 \\
0.936 \\
0.939 \\
0.934 \\
0.939 \\
0.940 \\
0.937 \\
0.933 \\
0.935 \\
0.937 \\
0.937 \\
0.936\end{array}$ & 0.684 \\
\hline $\begin{array}{l}\text { Project } \\
\text { schedule, } \\
\text { resources } \\
\text { and } \\
\text { procurement }\end{array}$ & $\begin{array}{l}\text { PSRP1 } \\
\text { PSRP2 } \\
\text { PSRP3 } \\
\text { PSRP4 } \\
\text { PSRP5 } \\
\text { PSRP6 } \\
\text { PSRP7 } \\
\text { PSRP8 }\end{array}$ & $\begin{array}{l}3.89 \\
3.63 \\
3.89 \\
3.84 \\
3.80 \\
3.51 \\
3.29 \\
3.40\end{array}$ & $\begin{array}{l}1.2960 \\
1.2670 \\
1.1770 \\
1.1470 \\
1.3210 \\
1.4320 \\
1.3080 \\
1.1820\end{array}$ & $\begin{array}{l}0.682 \\
0.664 \\
0.680 \\
0.651 \\
0.637 \\
0.750 \\
0.658 \\
0.604\end{array}$ & 0.890 & 0.604 & $\begin{array}{l}0.771 \\
0.770 \\
0.765 \\
0.801 \\
0.719 \\
0.793 \\
0.762 \\
0.776 \\
\end{array}$ & $\begin{array}{l}0.875 \\
0.877 \\
0.876 \\
0.878 \\
0.880 \\
0.868 \\
0.877 \\
0.882\end{array}$ & 0.540 \\
\hline $\begin{array}{l}\text { Project } \\
\text { scope creep } \\
\text { and } \\
\text { variation }\end{array}$ & $\begin{array}{l}\text { PSCV1 } \\
\text { PSCV2 } \\
\text { PSCV3 } \\
\text { PSCV4 } \\
\text { PSCV5 } \\
\text { PSCV6 }\end{array}$ & $\begin{array}{l}3.72 \\
3.52 \\
3.55 \\
3.45 \\
3.41 \\
3.43\end{array}$ & $\begin{array}{l}1.4800 \\
1.5310 \\
1.5040 \\
1.3930 \\
1.4390 \\
1.3730\end{array}$ & $\begin{array}{l}0.701 \\
0.703 \\
0.300 \\
0.736 \\
0.808 \\
0.724 \\
\end{array}$ & 0.910 & 0.757 & $\begin{array}{l}0.833 \\
0.853 \\
0.901 \\
0.861 \\
0.846 \\
0.819 \\
\end{array}$ & $\begin{array}{l}0.901 \\
0.901 \\
0.882 \\
0.896 \\
0.885 \\
0.897 \\
\end{array}$ & 0.727 \\
\hline $\begin{array}{l}\text { Project risk } \\
\text { and quality }\end{array}$ & $\begin{array}{l}\text { PRQ1 } \\
\text { PRQ2 } \\
\text { PRQ3 } \\
\text { PRQ4 } \\
\text { PRQ5 }\end{array}$ & $\begin{array}{l}3.80 \\
3.75 \\
3.20 \\
3.21 \\
3.21\end{array}$ & $\begin{array}{l}1.290 \\
1.291 \\
1.493 \\
1.468 \\
1.364\end{array}$ & $\begin{array}{l}0.760 \\
0.582 \\
0.667 \\
0.767 \\
0.812\end{array}$ & 0.882 & 0.688 & $\begin{array}{l}0.808 \\
0.756 \\
0.770 \\
0.826 \\
0.831\end{array}$ & $\begin{array}{l}0.846 \\
0.884 \\
0.868 \\
0.842 \\
0.832 \\
\end{array}$ & 0.638 \\
\hline $\begin{array}{l}\text { Project } \\
\text { completion }\end{array}$ & $\begin{array}{l}\text { PKOM1 } \\
\text { PKOM2 } \\
\text { PKOM3 } \\
\text { PKOM4 } \\
\text { PKOM5 } \\
\text { PKOM6 }\end{array}$ & $\begin{array}{l}2.69 \\
3.32 \\
2.44 \\
3.05 \\
3.68 \\
3.23\end{array}$ & $\begin{array}{l}1.4400 \\
1.5030 \\
1.3130 \\
1.2250 \\
1.1720 \\
1.357\end{array}$ & $\begin{array}{l}0.729 \\
0.698 \\
0.754 \\
0.685 \\
0.681 \\
0.688\end{array}$ & 0.748 & 0.641 & $\begin{array}{l}0.734 \\
0.839 \\
0.687 \\
0.650 \\
0.714 \\
0.739\end{array}$ & $\begin{array}{l}0.729 \\
0.698 \\
0.754 \\
0.685 \\
0.681 \\
0.688\end{array}$ & 0.577 \\
\hline
\end{tabular}


Table 3: Discriminant validity of constructs

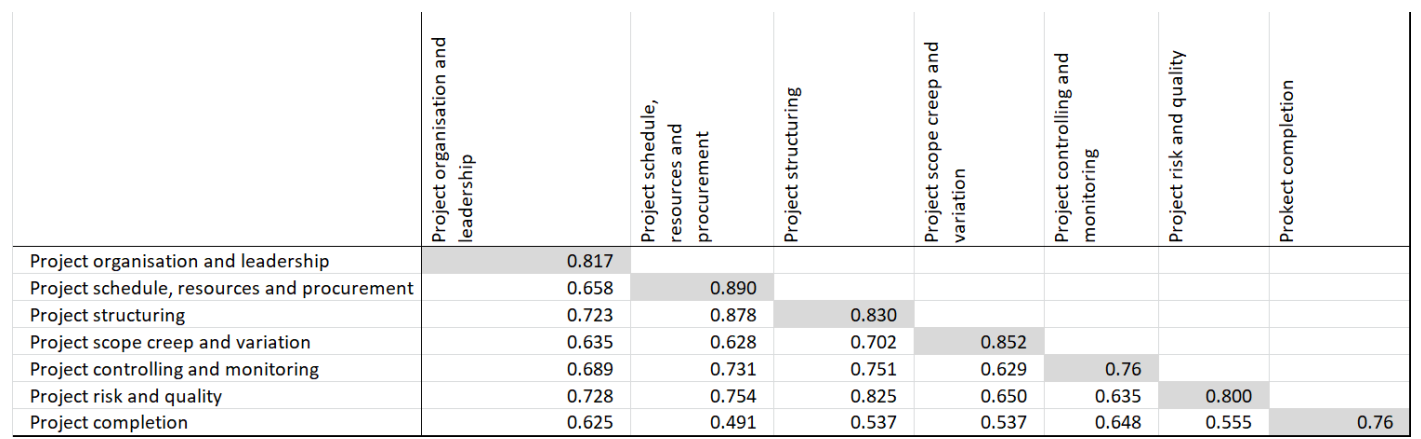

Table 4: Model fit indices

\begin{tabular}{|ll|ll|lr|}
\hline \multicolumn{4}{|l|}{ Absolute fit indices } & \multicolumn{4}{l|}{ Relative fit indices } & Parsimonious fit indices & \\
\hline GF1 & 0.961 & NFI & 0.999 & Normed chi-squared & 1.199 \\
AGFI & 0.903 & IFI & 1.000 & PNFI & 0.048 \\
RMSEA & 0.037 & RFI & 0.972 & PGFI & 0.048 \\
ECVI & 0.464 & TLI & 0.995 & AIC & 69.199 \\
\hline
\end{tabular}

\section{DISCUSSION OF RESULTS}

The main objective of the study is to investigate the links in a PM investigative framework. The central question posed is: What are the different factors in a project that contribute to better project outcomes? From Figure 2 it can be seen that project risk and quality (PRQ) has an R-squared value of 0.73 , and project completion (PKOM) has an R-squared value of 0.3 . From this it can deduced that the predictors ((a) project organisation and leadership (POGL), b) project control and monitoring (PCTR), c) project structuring (PSTR), d) project schedule, resources, and procurement (PSRP), and e) project scope creep and variation (PSCV) predict PRQ (project risk and quality) fairly well. Project risk and quality (PRQ) is also a good predictor of project completion (PKOM). Using the PM investigative framework, Figure 1 and Figure 2, the constructs in PM are studied to understand the linkages better. The research results provide a strong overall validation of the investigative framework, given the model fit indices in Table 4. The structural model is shown in Figure 2, with each of the hypotheses; Table 5 shows how each of the 19 hypotheses is supported.

The results were presented to the expert panel, who felt that the results showed a strong validation in respect of the predictors on PRQ and PKOM, and that these results were in accordance with what they expected. They expressed the need for an 'industry-wide' PMA - "perhaps a PMA with a catalogue of constructs and sub-scales which a practitioner could use to conduct PMA assessments". They did point out, however, that this might be a difficult exercise, as the complexities between large and small projects, and between between engineering, construction, and technology projects differ, and so to produce a more universal PMA tool while contributing to the project management arena might not be achievable. On a positive note, they felt that the PMA tool developed in this research was helpful in working towards a more robust framework.

The research evidence here supports the work by Siriram [2] for a more integrated PM investigative framework. Further research is still needed, however, to investigate other constructs in the PM investigative framework, including:

a) Project team satisfaction, customer satisfaction, the impact of engineering design on project risk and quality, and project outcomes [2].

b) Project stakeholder management and its impact on project risk [52].

c) Stakeholder group perceptions of project success [53].

d) Mir and Pinnington [54] point out that it is hard to model the links between project performance and project success, as it involves complex constructs. The work done in this paper contributes to a better understanding of the links. Mir and Pinnington [54] also note that there is insufficient understanding of the relationships between project performance and project success. These two additional constructs (project performance and project success) could be included in further research. 
e) The link between entrepreneurial organisations and project success, Martens [55, 56] found that project organisations that have a high entrepreneurial orientation achieve better project success.

f) Nguyen, Killen, Kock and Gemünden[57] point out the need for more innovative, responsive, and flexible decision-making instead of the more traditional rational and casual decisionmaking in the PMA arena. Perhaps innovative decision-making is another construct that could be included in further work.

While the need for more constructs may be required to obtain a deeper understanding of the PM process, it must be highlighted that the addition of further constructs will lead to a complicated PM investigative framework. More is not necessarily better. Future researchers should be cautious in this respect.

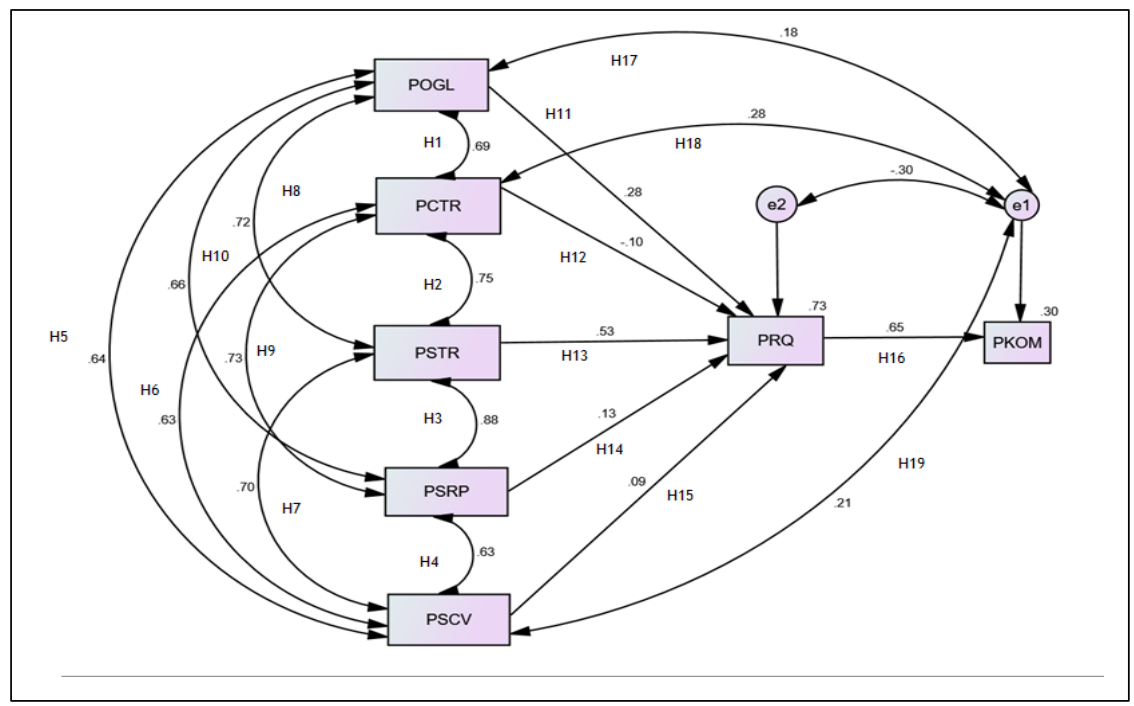

Figure 3: Research results

\section{LIMITATIONS OF THE RESEARCH}

The research was limited to four industry sectors (the electronics and electrical, ICT, mining, and manufacturing rail industries). A total of 330 projects were analysed. It would be beneficial to add more firms and projects to the analysis, and to be able to assess whether there are similarities and/or differences between industry sectors. However, obtaining such in-depth project information is problematic, as most firms are unwilling to disclose such detailed information.

Siriram [2] also conducted PMAs, and pointed out that the PMAs were conducted at a certain point in time, and that it would be beneficial to conduct a number of PMAs over the life of a project and to compare the results at different phases. However, in this paper we highlight that it would also be beneficial to conduct PMAs over the life cycle of a project. For example, if three PMAs were conducted on a typical project, all three PMA results should be included in the analysis. In addition, the participants in the research included project management personnel. The inclusion of other stakeholders may also be beneficial, and may yield different perspectives. Siriram [2] suggests that product managers, marketing managers, engineering managers, service managers, etc. could also be included. 
Table 5: Summary of hypotheses

\begin{tabular}{|c|c|c|c|}
\hline Hypothesis & Supported & Not Supported & $\begin{array}{l}\text { Significance } \\
\text { P-value }\end{array}$ \\
\hline $\mathrm{HI}$ & $\sqrt{ }$ & & $0.689, p<0.001$ \\
\hline $\mathrm{H} 2$ & $\sqrt{ }$ & & $0.750, p<0.001$ \\
\hline $\mathrm{H} 3$ & $\sqrt{ }$ & & $0.878, p<0.001$ \\
\hline $\mathrm{H} 4$ & S & & $0.628, p<0.001$ \\
\hline $\mathrm{H} 5$ & $\sqrt{ }$ & & $0.635, p<0.01$ \\
\hline $\mathrm{H} 6$ & $\sqrt{ }$ & & $0.629, p<0.001$ \\
\hline $\mathrm{H} 7$ & $\sqrt{ }$ & & $0.702, p<0.001$ \\
\hline $\mathrm{H} 8$ & $\sqrt{ }$ & & $0.729, p<0.001$ \\
\hline H9 & $\sqrt{ }$ & & $0.731, p<0.001$ \\
\hline $\mathrm{H} 10$ & $\sqrt{ }$ & & $0.658, p<0.001$ \\
\hline $\mathrm{H} 11$ & $\sqrt{ }$ & & $0.728, p<0.001$ \\
\hline $\mathrm{H} 12$ & $\sqrt{ }$ & & $0.635, p<0.001$ \\
\hline $\mathrm{H} 13$ & 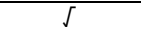 & & $0.825, p<0.001$ \\
\hline $\mathrm{H} 14$ & $\sqrt{ }$ & & $0.754, p<0.001$ \\
\hline $\mathrm{H} 15$ & $\sqrt{ }$ & & $0.650, p<0.001$ \\
\hline $\mathrm{H} 16$ & $\sqrt{ }$ & & $0.555, p<0.001$ \\
\hline $\mathrm{H} 17$ & & J & $0.180, p<0.001$ \\
\hline $\mathrm{H} 18$ & $\sqrt{ }$ & & $0.279, p<0.001$ \\
\hline $\mathrm{H} 19$ & & T & $-0.298, p<0.05$ \\
\hline
\end{tabular}

\section{FURTHER RESEARCH}

This research has made a contribution to knowledge by showing that a PM investigative framework linking different factors in project management can be developed. Further work may be directed as follows:

1. Conduct further PMAs and ascertain whether there are similarities and/or differences in respect of the PM investigative framework between industries.

2. Conduct further research to ascertain the possibility of including other constructs. This research did not include project team satisfaction and customer satisfaction levels, for example. How might project team satisfaction and customer satisfaction be accommodated in the PM investigative framework, and what are the possible linkages? Is project team satisfaction and/or customer satisfaction an indication of project quality and project completion? Other constructs, such as the inclusion of engineering design in the PM investigative framework, may also be investigated. Other constructs could also include decision-making and project performance and project success. These have already been discussed in section 4, points a-f.

3. Expand the research to include other industry sectors and countries, and ascertain whether there are similarities and/or differences in the PM investigative framework.

4. Compare the PM investigative framework in large and small projects, and ascertain whether there are any similarities and/or differences in the PM investigative framework.

Finally, further research should be devoted to understanding how the inclusion of other constructs in the PM investigative framework could be leveraged to improve project outcomes. 
In respect of the objectives of the research, the following criteria have been satisfied:

1. Using empirical data, 330 PMAs across four industry sectors were analysed, showing that a PM investigative framework linking the different PM constructs could be established.

2. The central question posed was, "What are the different factors in a project that contribute to better project outcomes?" This research answered that central question: it was shown that the five different constructs - a) project organisation and leadership (POGL), b) project control and monitoring (PCTR), c) project structuring (PSTR), d) project scheduling, resources, and procurement (PSRP), and e) project scope creep and variation (PSCV) - predicted project risk and quality (PRQ), and PRQ was also a good predictor of project completion (PKOM).

3. The output from this research provides direction for further empirical research in PM.

The PMAs constructed in this research consisted of seven constructs. Perhaps this needs to be refined, other constructs added, and some constructs combined. From the research conducted, it may be concluded that more empirical research is still required to understand the links in PM. The PM investigative framework was based on PMA data (i.e., project-relevant data). Further work could focus on conducting survey- or case study-based research, analysing the results, and comparing them with the findings obtained from the research evidence presented in this paper.

\section{REFERENCES}

[1] Siriram, R. 2017. A hybrid (soft and hard) systems approach to project management. SSRG International Journal of Industrial Engineering, 4, pp. 1-16.

[2] Siriram, R. 2018. Project management assessments (PMAs): An empirical study. South African Journal of Industrial Engineering, 29(1), pp.108-127.

[3] Miller, R. \& Lessard, D. 2009. The strategic management of large engineering projects: Shaping institutions, risks and governance. Cambridge, MA: Massachusetts Institute of Technology.

[4] Shehu, Z., Endut, I.R., Akintoye, A. \& Holt, G.D. 2014. Cost overrun in Malaysian construction projects: A deeper insight. International Journal of Project Management, 32, pp. 1471-1480.

[5] Young, R., Young, M., Jordaan, E. \& O'Connor, P. 2012. Is strategy being implemented through projects? Contrary evidence from a new leader in public management. International Journal of Project Management, 30, pp. 887-900.

[6] Atkinson, R., Crawford, L. \& Ward, S. 2006. Fundamental uncertainties in projects and the scope of project management. International Journal of Project Management, 24(8), pp. 687-698.

[7] Tahri, H. \& Drissi-Kaitounib, O. 2015. New design for calculating project management maturity (PMM). Procedia - Social and Behavioral Sciences, 181, pp. 171-177.

[8] Fringsdorf, O., Zuo, J. \& Zia, B. 2014. Critical success factors for project success in a defense environment. International Journal of Project Management, 32, pp. 803-814.

[9] Fernandes, G., Ward, S. \& Araújo, M. 2015. Improving and embedding project management practice in organizations - A qualitative study. International Journal of Project Management, 33, pp. 1052-1067.

[10] Jaafari, A. 2007. Project and program diagnostics: A systemic approach. International Journal of Project Management, 25(8), pp. 781-790.

[11] Qureshi, T.M., Warraich, A.S. \& Hijazi, S.T. 2009. Significance of project management performance assessment (PMPA) model. International Journal of Project Management, 27(4), pp. 378-388.

[12] Canonico, P. \& Sonderlund, J. 2010. Getting control of multi-project organizations: Combining contingent control mechanisms. International Journal of Project Management, 28, pp. 796-806.

[13] Baker, B. \& Fisher, D. 1998. Factors affecting project success. In: Cleland, D. \& King, W. (eds), Project management handbook. New York: Van Nostrand.

[14] Crawford, J. 2002. Project management maturity model: Providing a proven path to project management excellence. Havertown, Pennsylvania: Project Management Solutions Inc.

[15] Jugdev, K. \& Thomas, J. 2002. Project management maturity models: The silver bullets of competitive advantage. International Journal of Project Management, 33(4), pp. 4-14.

[16] Mittermaier, H. \& Steyn, H. 2009. Project management maturity: An assessment of maturity for developing pilot plants. South African Journal of Industrial Engineering, 20(1), pp. 95-107.

[17] Project Management Institute. 2008. A guide to project management body of knowledge, 4th edition. Pennsylvania: Project Management Institute.

[18] Chen, H.L. \& Lin., Y.L. 2018. Goal orientations, leader-leader exchange, trust, and the outcomes of project performance. International Journal of Project Management, 36, pp. 716-729.

[19] Guangshe, J., Yuting, C., Xiangdong, X., Jianguo, C., Jiming, C. \& Kewei, T. 2011. Program management organization maturity integrated model for mega construction projects in China. International Journal of Project Management, 29, pp. 834-845.

[20] Aubry, M., Muller, R., Hobb, B. \& Blomquist, T. 2010. Project management offices in transition. International Journal of Project Management, 28, pp. 766-778. 
[21] Kollveit, B.J., Karlsen, J.T. \& Grønhaug K. 2007. Perspectives on project management. International Journal of Project Management, 25, pp. 3-9.

[22] Yang, L., Huang, C. \& Wu, K. 2011. The association among project manager's leadership style, teamwork and project success. International Journal of Project Management, 29(3), pp. 258-267.

[23] Collyer, S. \& Warren, C.M.J. 2009. Project management approaches for dynamic environments. International Journal of Project Management, 27, pp. 355-364.

[24] Cao, Q. \& Hoffmann, J.J. 2011. A case study approach for developing a project performance evaluation system. International Journal of Project Management, 29(2), pp. 155-164.

[25] Crawford, P. \& Bryce, P. 2003. Project monitoring and evaluation: A method for enhancing the efficiency and effectiveness of aid project implementation. International Journal of Project Management, 21, pp. 363-373.

[26] Hazir, 0. 2015. A review of analytical models, approaches and decision support tools in project monitoring and control. International Journal of Project Management, 33, pp. 808-815.

[27] Pinto, J. 2014. Project management governance and the normalization of deviance. International Journal of Project Management, 32, pp. 376-387.

[28] Globerson, S. 1994. The impact of various work-breakdown structures on project conceptualization. International Journal of Project Management, 12, pp. 165-171.

[29] Larenas, G.S.\& Scasso, R. de H. 1999. Project-breakdown structure: The tool for representing the project system in project management. International Journal of Project Management, 3, pp. 157-161.

[30] Bjorvatn, T. \& Ward. A. 2018. Project complexity and team-level absorptive capacity as drivers of project management performance. International Journal of Project Management, 36, pp. 876-888.

[31] Zammori, F.A., Braglia, M. \& Frosolini, M, 2009. A fuzzy multi-criteria approach for critical path definition. International Journal of Project Management, 27, pp. 278-291.

[32] Basu, R. 2014. Managing quality in projects: An empirical study. International Journal of Project Management, 32, pp. 178-187.

[33] Kwak, Y.H. \& Smith, B.M. 2009. Managing risks in mega defense acquisition projects: Performance policy and opportunities. International Journal of Project Management, 27, pp. 812-820.

[34] Choi, J., Chung, J. \& Lee, D. 2010. Risk perception analysis: Participation in China's water PPP market. International Journal of Project Management, 28, pp. 580-592.

[35] Chapman, C. \& Ward, S. 2004. Why risk efficiency is a key aspect of best practices. International Journal of Project Management, 22, pp. 619-632.

[36] Chapman, C. 2006. Key points of contention in framing assumptions for risk and uncertainty. International Journal of Project Management, 24, pp. 303-313.

[37] Van Os, A., Van Berkel, F., De Gilder, D., Van Dyck, C. \& Groenewegen, P. 2015. Project risk as an identity threat: Explaining the development and consequence of risk disclosure in an infrastructure project. International Journal of Project Management, 33, pp. 877-888.

[38] Teller, J. \& Kock, A. 2013. An empirical investigation on how portfolio risk management influences project portfolio success. International Journal of Project Management, 31, pp. 817-829.

[39] Aziz, E.E. 2015. Project closing: The small process group with big impact. Paper presented at PMI Global Congress-EMEA, London, England.

[40] Wang, Y., Liu, Y. \& Canel, C. 2018. Process coordination, project attributes and project performance in offshore-outsourced service projects. International Journal of Project Management, 36, pp. 980-991.

[41] Görög. M. 2009. A comprehensive model for planning and controlling contractor cash-flow. International Journal of Project Management, 27, pp. 481-492.

[42] El-Sayegh, S.M. 2008. Risk assessment and allocation in the UAE construction industry. International Journal of Project Management, 26, pp. 431-438.

[43] Schwalbe. K. 2007. Information technology project management, 4th edition. Boston: Thompson Course Technology.

[44] Tam, V.W.Y \& Le, K.N. 2007. Quality improvement in construction by using a Vandermonde interpolation technique. International Journal of Project Management, 25, pp. 815-823.

[45] Zhang, H. 2007. A redefinition of the project risk success: Using vulnerability to open up the event consequence link. International Journal of Project Management, 25, pp. 694-701, doi:10.1016/j.ijproman.2007.02.004

[46] Van Wyk, R., Bowen, P. \& Atintoye, A. 2008. Project risk management practice: The case of a South African utility company. International Journal of Project Management, 26, pp. 149-163.

[47] Jha, K.N. \& lyer, K.C. 2007. Commitment, coordination, competence and the iron triangle. International Journal of Project Management, 25, pp. 527-540.

[48] Andersen, J.C. \& Gerbing, D.W. 1988. Structural equation modelling in practice: A review recommended two-step approach. Psychological Bulletin, 103, pp. 411-423.

[49] Hair, J.F. Jr., Anderson, R.E., Tatham, R.L. \& Black, W.C. 1998. Multivariate data analysis, $5^{\text {th }}$ edition. Prentice Hall, Upper Saddle River, New Jersey.

[50] Yang, C. \& Su, Yi-Fen. 2008. The impact of ERP implementation on corporate SCM performance: From an operational and information integration perspective. Proceedings of the 2008 IEEE Conference, pp. 1668 1672.

[51] Williams, L.J. \& Hazer, J.T. 1986. The antecedents and consequences of satisfaction and commitment in turnover models: A real analysis using latent variable structural equation models. Journal of Applied Psychology, 72, pp. 219-231. 
[52] Xia, N., Zou, P.X.W., Griffin, M.A., Wang, X. \& Zhong, R. 2018. Towards integrating construction risk management and stake-holder management: A systematic literature review and future research agendas, Internal Journal of Project Management, 36, pp. 701-715.

[53] Davies, K. 2014. Different stakeholder groups and their perceptions of project success. International Journal of Project Management, 32, pp. 189-201.

[54] Mir, F.A. \& Pinnington, A.H. 2014. Exploring the value of project management: Linking project management performance and project success. International Journal of Project Management, 32, pp. 202217.

[55] Martens, C.D.P., Carneiro, K.D.A., Martens, M.L. \& Silva, D. 2015. Relationship between entrepreneurial orientation and project management maturity in Brazilian software firms. Journal of Strategic Management, 14, pp. 72-91.

[56] Martens, C.D.P., Lacerda, F.M., Belfort, A.C. \& Freitas, H.M.R. 2016. Research on entrepreneurial orientation: Current status and future agenda. International Journal of Entrepreneurial Behavior and Research, 22, pp. 556-583.

[57] Nguyen, N.M., Killen, C.P., Kock, A. \& Gemünden, H.G. 2018. The use of effectuation in projects: The influence of business case control, portfolio monitoring intensity and project innovativeness. International Journal of Project Management, 36, pp. 1054-1067. 